\title{
Risk assessment and occupational safety and health protection in construction work on brownfields
}

\author{
A. P. Feige-Munzig \\ Berufsgenossenschaft der Bauwirtschaft, BG BAU, Germany
}

\begin{abstract}
Working on brownfields, the workers, who have to carry out these jobs, may be exposed to hazardous substances (chemicals and/or micro-organisms). This paper proposes a method of risk assessment and specification of measures for occupational safety and health protection, consisting of two steps: danger analysis and exposure assessment. Danger analysis means the investigation of the hazardous substances, of their physical, chemical and hazardous properties and the states of matter, being responsible for their mobility and emission behaviour. Exposure assessment starts with the so-called "working area analysis" - the investigation of the jobs that have to be carried out and of the working area conditions, which have a serious influence on the chance and level of exposure. Taking into account the possible absorption routes and limiting values used in occupational safety and health protection, the combination of the danger analysis data with the results of the exposure assessment leads to the risk assessment, the assessment of the possible health risk, and finally to the specification of safety measures. Risk assessment saves money: the less you know about the hazardous properties of a contaminated site, the higher the level of safety measures has to be, and the higher the costs of safety and health protection become.

Keywords: brownfields, contaminated sites, risk assessment, occupational safety and health protection, construction work, danger analysis, exposure assessment, safety measures, safety and health plan.
\end{abstract}

\section{Introduction}

During the remediation of contaminated sites hazardous substances are released causing a high risk to the health of the workers involved in these activities. To 
minimise this risk, safety measures need to be provided that match up to the risk potential of each individual project such that, on the one hand, the employees suffer no injury to their health and, on the other hand, the reclamation of a site of this nature remains economically viable.

In 1994, a concept for safety and health protection during work on contaminated sites was worked out in the Federal Republic of Germany, called Rules for Safety and Health Protection for Working on Contaminated Sites $B G R$ 128. Following the European Building Site Directive 92/57/EEC, a single directive on the basis of Article $118 \mathrm{a}$ of the EEC Treaty, those rules require that whenever construction work is to start on a brownfield site, the owner and the owner's coordinator for safety and health matters have to draw up a safety and health plan.

In particular as the basis for the call for tenders the safety and health plan needs to list the hazardous substances on the future building site, it needs to evaluate the safety and health risks for the workers and, on the basis of this evaluation, it needs to determine the special protection measures required for handling these substances. In this sense risk assessment is the most important tool to achieve this aim (Figure 1).

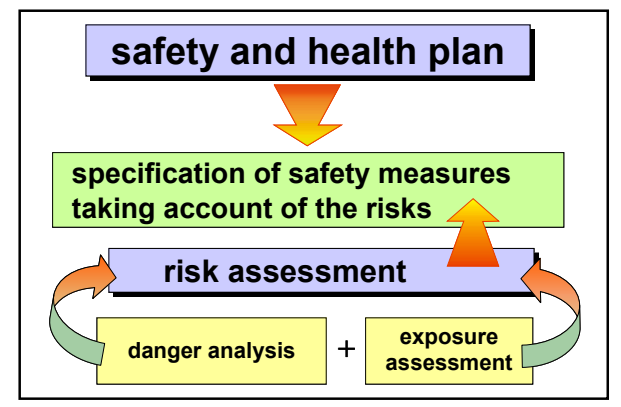

Figure 1: $\quad$ The owner's tasks: safety and health plan and risk assessment.

Risk assessment for construction work on brownfields requires occupational safety and health protection in relation to hazardous substances and microorganisms depending on the following steps (Figure 2):

- investigation for hazardous substances such as chemicals and microorganisms;

- danger analysis to investigate the chemical, physical, toxic and other hazardous properties (e.g. infection) of the hazardous substances;

- exposure assessment to assess the levels of emission exposure combining the results of the working area analysis with the mobility properties of the substances;

- risk assessment to assess for each separate activity ( $\rightarrow$ working area analysis) the dimension of the safety and health risk combining the results of the exposure assessment with the hazardous properties of the contaminants $(\rightarrow$ danger analysis). 


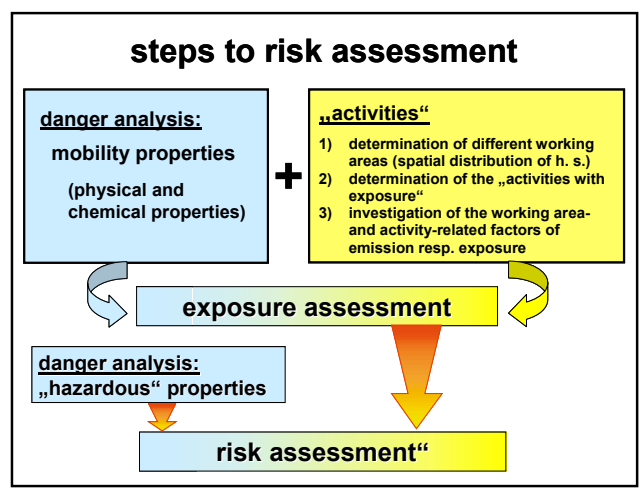

Figure 2: $\quad$ Steps to risk assessment.

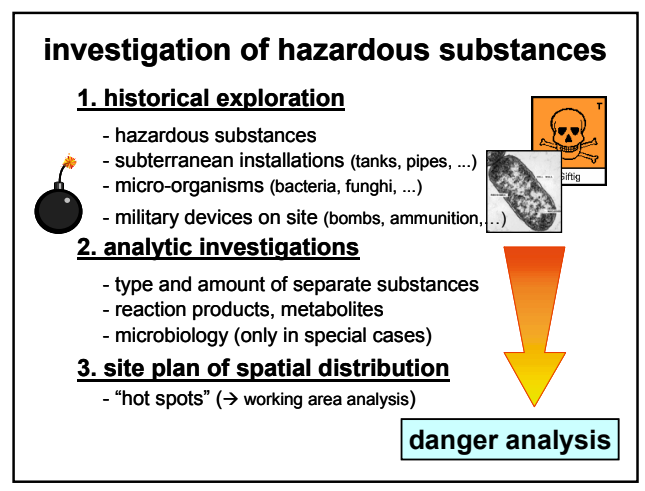

Figure 3: Investigation of hazardous substances.

\section{Investigation for hazardous substances}

As the first step to risk assessment those hazardous substances that are suspected of being on the site have to be investigated by means of the so-called Historical Investigation into the past, historical use(s) of the brownfields site. This data is required not only for establishing the testing parameters for further substance investigation, for example, by means of a chemical analysis of the substances, but also for the safety planning of the subsequent site work necessary to investigate a suspected area. The Historical Investigation also covers the investigation of "inherited military devices", i.e. whether unexploded bombs or similar objects are to be expected on the site (Figure 3).

Based on the results of the Historical Investigation the type, quantity and spatial distribution of the existing hazardous substances need to be determined by means of exploratory measures (prospecting, drilling, sampling, analysis etc.). Within the framework of the analyses it is always necessary to look for separate 
substances. Although simple data from summation parameters ("HC-(IR)" = all hydrocarbons, "BTEX" = benzol, toluol etc) already provide useful information about the existence of substances from separate substance groups, they do not permit an assessment of the danger potential. Enormous differences in the risk may be present even within groups of related substances. This can be demonstrated by a simple comparison of the air limit values of benzol (1ppm) and toluene $(50 \mathrm{ppm})$ from the BTEX group or the air limit value of pentane $(1000 \mathrm{ppm})$, n-hexane (50 ppm) and heptane (500 ppm) in the HC-group.

With ambivalent values, the health risk must always be assessed on the basis of the highest potential risk ("worst-case"): for example, with cyanide contamination, the cyanides need to be examined to see whether they occur in a complex bound form, i.e. in a fairly stable state that is bioavailable only to a trivial extent, or whether they occur in a highly toxic, easily liberated form. The sole indication of the "cyanide" summation parameter inevitably leads to higher-level protection measures and hence to greater costs.

In the case of heavy metals, the concentrations of individual metals are given, containing limited informative value about the actual risk present, which depends on the bioavailability and hence the form or type of bond of the heavy metal.

An investigation of the bond type is very costly and, given the large number of possibilities, ultimately does not achieve its aim. One possible way, however, is to use the Historical Investigation, e.g. during the dismantling of industrial plants, to establish how the substance in question was dealt with and in what form or combination, on the respective site, and in what reactors and pipelines these materials can be expected.

With soil contamination, observation of the geochemical or hydrochemical milieu (e.g. $\mathrm{E}_{\mathrm{h}} \mathrm{pH}$ potential) helps to assess the type of chemical combination and hence the bioavailability of heavy metals. For example, under conditions of reduction, hermetic sealing in soils with a high organic content, mercuric chlorides used to impregnate wood may be reduced to metallic mercury. In particular account should be taken of the products of the change, sometimes even entire series of degradations, such as the degradation of certain chlorinated hydrocarbons to vinylchloride (VC) or the denitrification of TNT via DNT to aromatic amines by microbial activity. All reaction products or even "metabolites" possess different chemical-physical and/or toxicological properties from the original, initial products that were processed or produced on the site, a factor that may have an effect on safety planning.

Further key factors in the investigation for hazardous substances are

a) the establishment of the existing concentration of hazardous substances, and

b) the spatial distribution of the substances in the contaminated zone.

In conjunction with its properties (see Section 3 on "Danger Analysis") the concentration of a substance in the soil, in masonry, groundwater etc. is a measure of the extent to which safety planning must allow for this. Ascertaining the spatial distribution of the substances helps to establish different "working areas" with different graduated measures, e.g., the excavation depth at which contaminated material can be expected and from what point in time or from what depth special safety measures are necessary. 
It is not only the risks arising from "chemistry" that have to be accounted for, but also the biological hazard caused by pathogenic germs (bacteria, fungi, viruses) or human endoparasites (cf. European Directive on Biological Working Materials EEC 90/679/EEC). An investigation into biological hazards should always be carried out if

- biological agents were used on the site;

- certain materials or other local conditions favour the survival, growth or possibly the propagation of germs;

- the presence of germs or parasites can be expected in certain areas, for example, in remediation of suspected areas used by the leather industry (anthrax pathogens), or from sewage ditches, drains etc.; or

- microbiological remediation of the soil is required, for which our firm has prepared a set of instructions on the action to be taken in determining safety measures.

\section{Danger analysis}

The task of danger analysis is required to determine the properties of the assumed or analytically determined substances (Figure 4) with regard to mobility and hazards; to use these properties for the assessment as to whether dangerous quantities of the hazardous substances may be released during or even because of the work; and to assess what the chances or risks are of intake or exposure via the different absorption routes - inhalation, ingestion, and/or dermal contact. Table 1 shows the most important danger characteristic and the corresponding evaluation parameters.

In principle, the danger analysis has to be done for every substance assumed or analytically determined on the site. However, a broad mixture of different substances and their microbial metabolism products are often found at brownfield sites. Therefore, the most practical method would be to select those individual substances as indicator substances from the existing spectrum of hazardous substances having the most critical assessment parameters with regard to the respective danger characteristics:

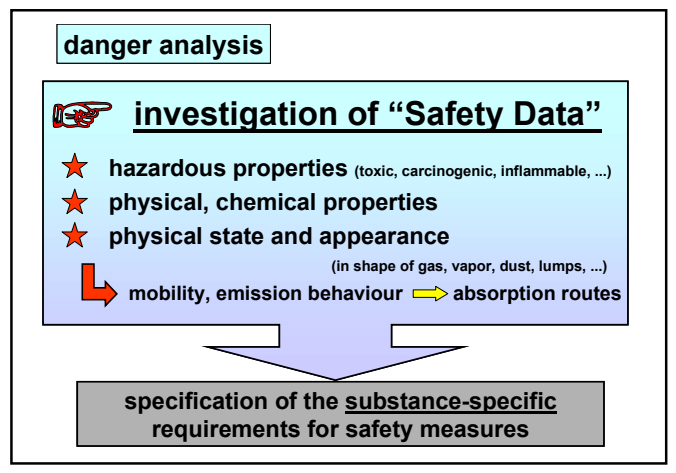

Figure 4: Danger analysis. 
Table 1: Assignment of danger characteristics to characteristic groups and evaluation parameters.

\begin{tabular}{|l|l|l|}
\hline $\begin{array}{l}\text { Characteristic } \\
\text { group }\end{array}$ & $\begin{array}{l}\text { Danger } \\
\text { characteristics }\end{array}$ & $\begin{array}{l}\text { Typical evaluation parameters } \\
\text { (hazards, mobility) }\end{array}$ \\
\hline $\begin{array}{l}\text { Inflammable } \\
\text { substances }\end{array}$ & $\begin{array}{l}\text { explosive } \\
\text { possibly explosive } \\
\text { highly inflammable } \\
\text { easily inflammable } \\
\text { inflammable }\end{array}$ & $\begin{array}{l}\text { explosion limit values flashpoint } \\
\left.\text { vapour pressure [mbar }\left(20^{\circ} \mathrm{C}\right)\right] \text { firing } \\
\text { power }\end{array}$ \\
\hline $\begin{array}{l}\text { Explosive } \\
\text { substances }\end{array}$ & explosive & chemical reactivity \\
\hline $\begin{array}{l}\text { Combustible } \\
\text { substances }\end{array}$ & combustible & available oxygen \\
\hline Toxic substances & $\begin{array}{l}\text { highly toxic } \\
\text { toxic } \\
\text { injurious to health }\end{array}$ & $\begin{array}{l}\text { atmospheric limit value LC / LD 50 } \\
\text { absorption route skin contact boiling point } \\
\left.\text { vapour pressure [mbar }\left(20^{\circ} \mathrm{C}\right)\right] \text { ability of } \\
\text { sublimation aqueous solubility }\end{array}$ \\
\hline $\begin{array}{l}\text { Substances } \\
\text { damaging the } \\
\text { skin/mucous } \\
\text { membrane }\end{array}$ & $\begin{array}{l}\text { caustic } \\
\text { irritant }\end{array}$ & $\begin{array}{l}\text { atmospheric limit value } \\
\left.\text { vapour pressure [mbar }\left(20^{\circ} \mathrm{C}\right)\right] \mathrm{pH} \text { value } \\
\text { skin contact aqueous solubility }\end{array}$ \\
\hline $\begin{array}{l}\text { Substances with } \\
\text { special danger } \\
\text { potential }\end{array}$ & $\begin{array}{l}\text { carcinogenic } \\
\text { mutagenic } \\
\text { teratogenic or } \\
\text { toxic to } \\
\text { reproductive cells }\end{array}$ & $\begin{array}{l}\text { atmospheric limit value boiling point } \\
\left.\text { vapour pressure [mbar }\left(20^{\circ} \mathrm{C}\right)\right] \text { ability of } \\
\text { sublimation absorption route carcinogenic } \\
\text { category C 1-3 mutagenic category } \mathrm{M} 1-3 \\
\text { reproduction toxicity categories } \mathrm{R}_{\mathrm{F}} \text { and } \mathrm{R}_{\mathrm{E}} \\
1-3\end{array}$ \\
\hline Allergens & $\begin{array}{l}\text { atmospheric limit value vapour pressure } \\
\text { sensitising } \\
\text { absorption route }\end{array}$ \\
\hline $\begin{array}{l}\text { Micro-organisms } \\
\text { sensitising } \\
\text { properties }\end{array}$ & $\begin{array}{l}\text { Risk group } \\
\text { Colony forming unit }\left[\mathrm{CFU} / \mathrm{m}^{3} \text { ] }\right.\end{array}$ \\
\hline
\end{tabular}

- $\quad$ the lowest atmospheric limit value

- the lowest explosion limit value

- the property of damaging the skin or being absorbed through the skin,

- classifications such as - carcinogenic category C 1-3

- $\quad$ mutagenic category M 1-3

- $\quad$ reproduction toxicity categories $\mathrm{R}_{\mathrm{F}} / \mathrm{R}_{\mathrm{E}} 1-3$

In selecting the indicator substances consideration must be given to whether the substance that is to be selected according to the danger characteristics exists in a relevant quantity or concentration.

By using the boiling point or steam pressure as well as the aqueous solubility of the substances and allowing for the environmental conditions during the construction phase, an assessment can be made of the extent to which the individual substances can be expected to be particle-bound, in aqueous solution, in fluid form or in vaporous or gaseous form. 
To avoid having to assign every single danger characteristic to the assessment parameters, it is possible to combine "related" characteristics into a characteristic group. Table 1 contains a suggestion for this method of assignment.

Other assessment parameters are the physical-chemical properties of the substances: explosion limit values (LELV, UELV), flashpoint, firing power, boiling temperature, steam pressure, aqueous solubility, volatility (sublimation tendency).

In addition, the volatility has to be allowed for, because some substances, for example, from $\mathrm{PAH}, \mathrm{HCH}$, dioxin, have a high sublimation tendency, i.e. the transition from the solid state of aggregation to the vapour phase and vice versa. Benzo(a)pyrene has a high boiling point $\left(495.5^{\circ} \mathrm{C}\right)$ and a correspondingly low steam pressure $\left(7.3 \times 10^{-9} \mathrm{mbar}\right.$ at $\left.20^{\circ} \mathrm{C}\right)$, but it has a tendency to sublimate in an air current when powered filtering devices are used so a composite filter for particles and organic gases and vapours should be employed.

The evaluation of the form or type of hazardous substances and their mobility (for example, behaviour as air-borne dust) is a major factor in the danger analysis. It is not only the analytically determined concentration of a substance that is the decisive evaluation criterion for protective measures but also the exact description of the material that is highly important. The comparison of two samples will shed light on these problems: within a sandy matrix we find lumps of tar (sample 1) or filter-dusts containing PAH (sample 2) (Figure 5). The chemical analysis of sample 1 shows far higher benzo-a-pyrene contents than in the other case, because small pieces of tar were included in the sample. All other things being equal, the comparably lower level of soot contamination in the sand nevertheless constitutes a higher risk, because the soot becomes airborne much more easily than the particles in the lumps of tar.

At the same time attention must be paid to changes arising during the actual work in the states of aggregation or the form of appearance, or even through the protective measures themselves creating new dangers, for example by dissolving water-soluble hazardous substances when using water to dampen down dust.

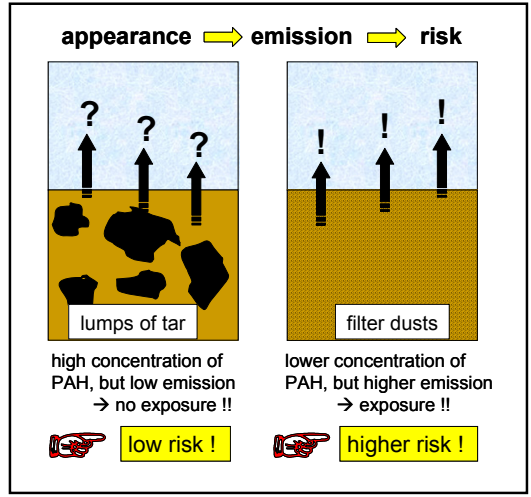

Figure 5: The form of appearance determines the risk. 
Danger analysis is the basis for the determination of substance-related protective measures (Figure 4), because it is the properties of the substances that decide what type of protective clothing or breathing equipment is to be selected. The presence of substances that can be absorbed by the skin is a basic factor in the choice of protective clothing (coated or uncoated), just as the water-solubility of combustible substances also influences the choice and provision of suitable extinguishing agents.

With insufficient knowledge of the separate substances, their properties and the forms in which they occur, the "worst case" must always be assumed, i.e. they must be assigned for health-protection purposes to the most critical category (volatile, bioavailable, toxic) of the compound or form.

\section{Exposure assessment - working area analysis}

The first step of the working area analysis is to divide the construction site "brownfield" into different "working areas", corresponding either to the spatial distribution of the hazardous substances, to the spatial division found on the site (e.g. industrial site with different plants and facilities), or to the different types of jobs which have to be performed on the site (Figure 6).

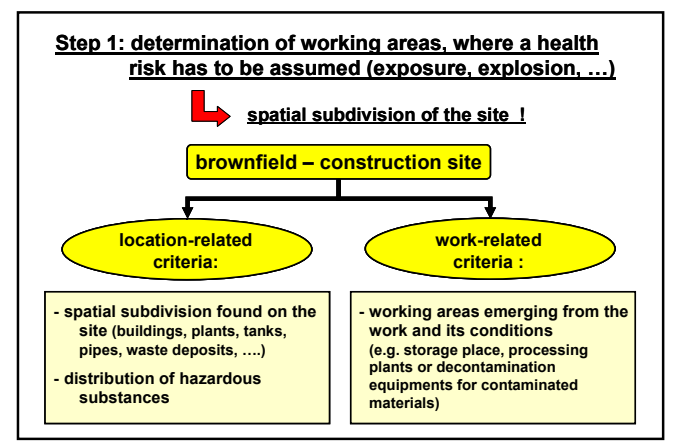

Figure 6: Working area analysis step 1.

Safety measures must provide adequate protection for each separate activity. Therefore an important step in risk assessment is to provide a detailed analysis of the planned work procedure as regards the steps necessary for its execution, the jobs arising from this (machine operator, truck driver, etc) and the types of activities (manual work, cleaning, servicing and maintenance of machines and plants, supervisory activities, etc) (Figure 7).

A record must be kept and an assessment made of all activities that may involve contact with hazardous substances (e.g. the excavator operator does not only operate the excavator, but he also has to carry out maintenance work on the equipment that has been contaminated during the course of his work, and the appropriate decontamination and other safety measures must be specified for this). 


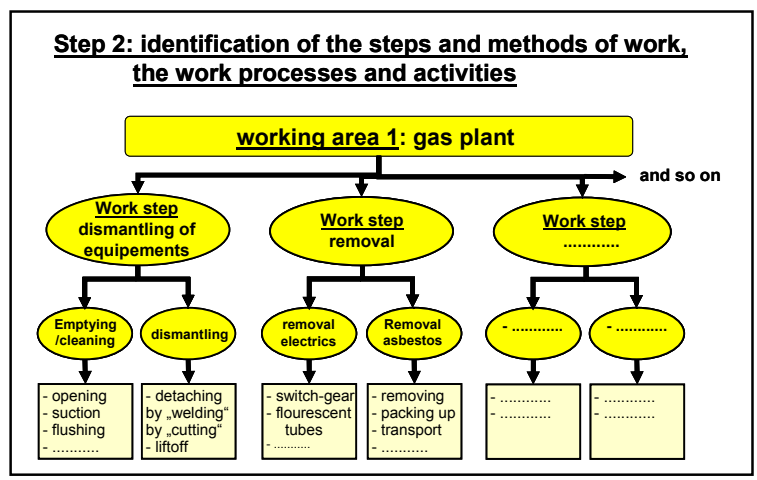

Figure 7: $\quad$ Working area analysis step 2.

So far we have collected the data to assess whether an exposure or dangerous situation could occur or not. But for risk assessment and the specification of appropriate safety measures we need further work- and location-related data in order to estimate the magnitude of the "event" or danger. In this phase of "planning", the results of measurements are not available and therefore it is necessary to use "soft" criteria:

- $\quad$ weather conditions to be assumed during the execution of the work

- $\quad$ the source of the emission (e.g., at a certain point or over a certain area

- $\quad$ one might expect low or high emission rates)

- $\quad$ working method with high or low emission potential

- $\quad$ environmental conditions (e.g., working in a closed room or on top of a hill would result in higher or lower concentrations of dust or vapours)

- $\quad$ proximity of the activity to the point of the source of the emission

- $\quad$ frequency and period of activity in the emission's danger zone, which might lead to a range of potential risks of exposure.

The investigation of this data may be called "step 3 of the working area analysis".

Combining the data of the mobility of the substances and their exposureroutes, according to their state of aggregation, with the results of the working area analysis it is possible to estimate the magnitude of an exposure and the probability that unacceptable hazards may be encountered on site

\section{Risk assessment}

Combining the hazards of the substances (see "danger analysis", Table 1) with the data of the exposure assessment it is possible to provide a qualitative assessment of the risk in terms of a minimum or maximum likelihood of risk. For instance:

- $\quad$ High exposure to a "harmless" substance may lead to low health risk.

- $\quad$ Low exposure to a serious toxic substance may cause a high health risk.

- $\quad$ Cold temperatures in winter time may decrease the vaporisation of highly volatile, inflammable organic carbons and consequently the risk that such 
Table 2: $\quad$ Proposal to present the results of exposure/risk assessment.

\begin{tabular}{|c|c|c|c|c|c|c|}
\hline \multirow{2}{*}{$\begin{array}{l}\text { PROJECT: } \\
\text { GAS PLANT } \\
\text { working area: } \\
\text { tar pit } \\
\text { work step: }\end{array}$} & \multirow[t]{2}{*}{$\begin{array}{l}\text { Activity / Staff } \\
\text { a) by machine } \\
\text { b) by hand }\end{array}$} & \multicolumn{4}{|c|}{$\begin{array}{c}\text { Exposure } / \text { Risk assessment } \\
\begin{array}{c}+=\text { high, , }+-=\text { medium, }-=\text { low, } \\
0=\text { no exposure } / \text { risk })\end{array}\end{array}$} & \multirow[t]{2}{*}{$\begin{array}{l}\text { Explosion } \\
\text { risk }\end{array}$} \\
\hline & & $\begin{array}{l}\text { contam. } \\
\text { materials }\end{array}$ & $\begin{array}{l}\text { contam. } \\
\text { liquids }\end{array}$ & $\begin{array}{l}\text { gas / } \\
\text { vapour }\end{array}$ & $\begin{array}{l}\text { dust / } \\
\text { aerosol }\end{array}$ & \\
\hline \multirow{6}{*}{$\begin{array}{l}\text { excavation } \\
\text { "tar pit " }\end{array}$} & a) excavator & 0 & 0 & + & 0 & \multirow[t]{9}{*}{ - } \\
\hline & a) loader & $\mathbf{0}$ & 0 & + & $\mathbf{0}$ & \\
\hline & a) truck & 0 & 0 & - & 0 & \\
\hline & b) worker & +- & + & + & + & \\
\hline & b) foreman & - & - & - & - & \\
\hline & b) surveyor & $\mathbf{0}$ & $\mathbf{0}$ & - & - & \\
\hline \multirow{3}{*}{$\begin{array}{l}\text { cleaning of } \\
\text { excavator } \\
\text { loader }\end{array}$} & b) outside (steam) & - & + & 0 & $\mathbf{0}$ & \\
\hline & $\begin{array}{l}\text { b) inside dry } \\
\text { (vac cleaner) }\end{array}$ & $\mathbf{0}$ & $\mathbf{0}$ & $\mathbf{0}$ & + & \\
\hline & b) inside, wet & $\mathbf{0}$ & + & $\mathbf{0}$ & $\mathbf{0}$ & \\
\hline
\end{tabular}

compounds will reach inflammable concentrations in the air, especially on top of a hill!

A suggestion for the presentation of this assessment is shown in Table 2.

\section{Specification of protective measures}

On the basis of a risk assessment similar to that presented above, it is possible to define the appropriate protective equipment for each activity. Whenever this method of risk-based specification of protective measures is applied, it may be that two people, while working in the same working area, may be required to wear different protective equipment. Utilizing different protective gear within the same working area may not be readily understood by the workers; however, with proper instruction about the different risks of different "jobs", they will better understand and accept that such safety measures will reduce the risk and cost to all.

Exploratory drilling in a special waste dump as an example. The worker, who works longest and closest to the source of emission, places the pipework and screws on the new rod assemblies, removes the core from the central column, and is generally always proximate to the point of the emission is given a complete protective suit with breathing apparatus that is independent of the ambient air. On the other hand, the foreman driller, who normally only operates the controls of the drilling equipment, and comes into the working area five times a day to help his colleagues with certain jobs, could manage with a disposable protection suit and a filter mask, depending on the substances present (Figure 8). While this is only an example, the selection of protective measures must always be made according to the premise that effective technical measures (ventilation, equipment for air supply on earth-moving machinery) must necessarily take precedence over the use of personal protective equipment (PPE). 
PPE always means an additional strain on the human body, e.g. through heat accumulation in protective clothing or the extra weight of breathing equipment, which leads in turn to reduced performance, and not only because of the associated regulations governing limits on wearing periods and work intervals.

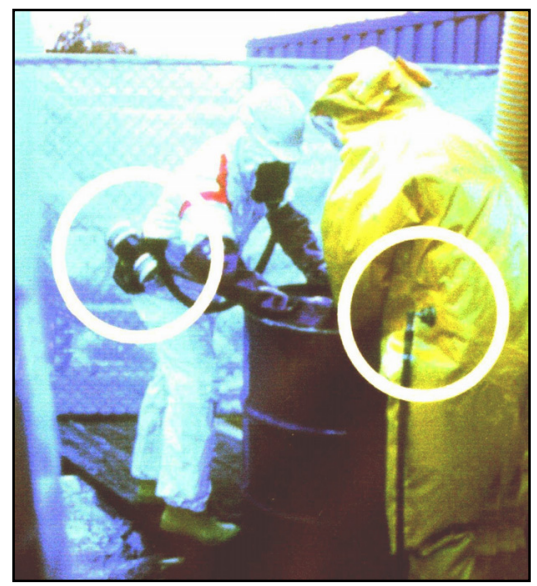

Figure 8: Different risks require different protective equipment.

\section{Conclusions}

Qualitative risk assessment of whether high or low exposure or other dangerous situations related to hazardous substances are to be expected during work on brownfields is a suitable method for ensuring that:

a) appropriate measures are taken at each workplace that conform to the project-specific risks utilizing state-of-the-art knowledge,

b) the acceptance of the protective measures by all participants is increased by avoiding exaggerated measures, and

c) the costs remain within an acceptable framework.

Risk assessment is not only a part of any safety and health protection scheme for employees but also an important component in ascertaining the optimum, most cost-effective working method, which makes it an integral part of any remediation project.

\section{References}

[1] Council Directive 92/57/EEC of 24 June 1992 on the implementation of minimum safety and health requirements at temporary or mobile construction sites

[2] BGR 128 - Rules for Safety and Health Protection for Working on Contaminated Sites; Germany, 1997 (updated 2006);

[3] Andreas P. Feige-Munzig, Gefährdungsbeurteilung bei Arbeiten in kontaminierten Bereichen, Tiefbau 2/2005, S. 71-77 